Daria Vladimirovna Palitsyna ${ }^{1}$

Nizhny Novgorod State University of

Engineering and Economics, Knyaginino (Russia)
SCIENTIFIC REVIEW ARTICLE

DOI: $10.5937 /$ ekonomika2102070V

Received: December, 08. 2020.

Accepted: February, 19. 2021.

\title{
THE MAIN FACTORS AFFECTING THE COMPETITIVENESS OF THE OIL PROCESSING COMPLEX
}

\begin{abstract}
The development of the economic situation in Russia in recent years is characterized by the achievement of stabilization at the macro level, the strengthening of investment activity, the expansion of the scope of activities of the processing industry, the strengthening of public confidence in domestic goods and finished products. The research urgency is caused by the fact that in Russia economic competition becomes more acute in oil and fat processing sector, also has a problem of lack of training organizations to consider the impact of external factors and competitive advantages of the industry to ensure financial stability. The purpose of the study is to study the features of factors affecting the competitiveness of the oil processing complex. On the basis of sources of economic literature, the authors studied the competitiveness of vegetable oil production by comparison and identified the problems of insufficient methodological support for studying the impact of factors that determine the current state of the vegetable oil market, methods and approaches for assessing the competitiveness of organizations. The leading direction is a comprehensive approach presented by the authors in the article, including the study of domestic and international experience in determining the factors of internal and external environment that affect the development of the industry. The study of the traditional system of assessing the competitiveness of vegetable oils is given, proposed by Russian and foreign scientists. As a result of the conducted research it is established that modern domestic and foreign methods of the analysis of the competitiveness of vegetable oils do not differ in high quality and have shortcomings. The authors noted that the analysis of the concept of competitiveness of vegetable oils does not take into account the quality indicators are not always fully represented the composition and structure of the concept, not justified organizational and methodological approaches to the analysis of the concept of competitiveness applicable to vegetable oils. The researchers note the need for an objective assessment of the analysis of the concept of competitiveness of vegetable oils to supplement it with a more detailed study of improving the level of competitiveness. In their opinion, the lack of a single definition of the term "competitiveness of products" is one of the most difficult in the formation of an adequate approach to the assessment of the phenomenon. This leads to the fact that the most common assessment is a comparative assessment of similar vegetable oils with ethanol. The study conducted by the authors has scientific and practical significance and will allow to develop a methodological apparatus (parameters and criteria for assessing the level of competitiveness of vegetable oils) in accordance
\end{abstract}

${ }^{1}$ ya.199517fttbkisru2011@yandex.ru, ORCID ID: 0000-0002-9754-3110. 
with the requirements of the industry in the world economy, as well as to form a set of strategic and tactical management decisions to improve the competitiveness of vegetable oils and mechanisms of interaction in creating competitive advantages and strengthening the market position of vegetable oils.

Key words: competitive advantage, competitive products, oil and fat industry, oil, trends, factors.

JEL classification: $L 6, Q 1$

\title{
ГЛАВНИ ФАКТОРИ КОЈИ УТИЧУ НА КОНКУРЕНТНОСТ КОМПЛЕКСА ЗА ПРЕРАДУ УЉА
}

\begin{abstract}
Апстракт
Развој економске ситуације у Русији последњих година карактерише постизање стабилизације на макро нивоу, јачање инвестиционе активности, проширење обима активности прерађивачке индустрије, јачање поверења јавности у домаћу робу и готове производе. Неопходност истраживања узрокована је чињеницом да у Русији економска конкуренција у сектору прераде уља и масти постаје све оштрија, такође постоји проблем недостатка организација за обуку које би разматрале утищај спољних фактора и конкурентску предности индустрије како би се осигурала финансијска стабилност. Сврха истраживања је проучавање карактеристика фактора који утичу на конкурентност комплекса за прераду уља. На основу извора економске литературе, аутори су компарацијом проучавали конкурентност производње биљног уља и идентификовали проблеме недовољне методолошке подрике за проучавање утицаја фактора који одређују тренутно стање на тржишту биљног уља, методе и приступе за процену конкурентности организаџија. Водећи правач је свеобухватан приступ који су аутори представили у раду, укључујући сагледавање домаћег и међународног искуства у одређивану фактора унутрашьег и спољног окружења који утичу на развој индустрије. Изложена је студија традиционалног система процене конкурентности биьних уља, коју су предложили руски и страни научници. Као резултат спроведеног истраживања утврђено је да се савремене домаће и стране методе анализе конкурентности биљних уља не разликују у квалитепу и да имају недостатке. Аутори су приметили да анализа кониепта конкурентности биљних уља не узима у обзир показатеље квалитета, да нису увек у потпуности представљени састав и структура концепта, да нису оправдани организациони и методолошки приступи анализи концепта конкурентности који се примеюују у области биљних уља. Истраживачи примећују потребу за објективном проценом анализе концепта конкурентности биљних уља како би га допунили детаљнијом студијом побољиања нивоа конкурентности. Према юиховом мишљењу, недостатак јединствене дефиниције појма ,,конкурентност производа“ “један је од најтежих у формирању адекватног приступа процени појаве. То доводи до чињенице да је најчешћа процена упоредна процена сличних биљних уља са етанолом. Студија коју су спровели аутори има научни и практични значај и омогућиће да се развије методолошки апарат (параметри и критеријуми за проиену нивоа конкурентности биљних уља) у складу са захтевима
\end{abstract}


индустрије у светској економији, као и да се формира скуп стратешких и тактичких управљачких одлука за побољшање конкурентности биљних уља и механизама интеракиије у стварању конкурентске предности и јачању тржишне позищије биљних уљь.

Кључне речи: конкурентска предност, конкурентни производи, индустрија уљь и масти, уље, трендови, фактори.

\section{Introduction}

An important part of the Russian food industry is the production of vegetable and animal oils. The production of vegetable oil is a socially important commodity consumed by households, used by catering enterprises, and in industry for further processing. The idea of competitiveness of production of oil and fat branch of a vegetable origin in modern conditions became one of the main along with judgment on efficiency of production of vegetable oils. In ensuring the food security of the country, the task of achieving a high level of competitiveness of the processing industry is one of the key for economic entities that are engaged in expanding the production of oils from sunflower seeds, corn, olive, rape (Almazov \& Katischin, 2014, p. 23).

The analysis of scientific literature showed that competition is a driving force of development of society, has a positive impact on the growth of investment, increase in the volume and quality of finished products. It should be noted that most scientists consider the competitiveness of products as a property of the object, which can be characterized by the ability to compare the real satisfaction of a need with similar objects.

The economic literature identifies the following problems that adversely affect the development of the fat-and-oil industry:

- macroeconomic instability in the country;

- low share of investments in fixed assets;

- insufficient implementation of innovations in the technological process and organization of production;

- $\quad$ lack of implementation of achievements of modern research results of the use of non-waste, frugal, technologies, equipment in order to optimize costs to ensure competitive pricing of products;

- availability of financial risks;

- lack of public-private partnership.

The purpose of the study-to show the need for analysis and consideration of factors affecting the development of the fat and oil industry, the aggregation of all signs of their set in assessing the competitiveness of organizations and products to determine the effective financial condition of organizations. This requires not only the definition of generalizing characteristics, but also the formation of an assessment taking into account the establishment of the relationship between the indicators of each factor and the analysis based on the ordering of its individual elements according to certain properties and principles.

The scientific significance of the work is to systematize and complement the factors of internal and external environment, allowing taking into account the conditions, 
direct control over which organizations cannot exercise and the conditions on which they can have an impact as a result of economic activity and work with counterparties on business transactions and transactions.

The hypothesis of the study is based on the objective need in modern conditions for the organizations of the processing oil and fat industry to improve the assessment and analysis of factors affecting the increase of its competitiveness. This includes the allocation of the totality of real factors of the main, which are based on the advantages of the organization, as well as the modernization and elimination of certain shortcomings of existing methods in order to fundamentally change the algorithm of integrated assessment of factors.

\section{Materials and methods}

According to the authors, insufficient attention to the impact of environmental factors on food industry organizations reduces the effectiveness of decision-making to improve their competitiveness. It should be noted that the production of sufficient quantities of oils from sunflower seeds, corn, olives, and rapeseed contributes not only to meeting the needs of the population, but also determines the creation of new social needs that lead to the creation of new production products based on their further processing. Today, the Russian oil and fat market has a good potential for development, despite the problems.

In modern conditions, economists estimate the volume of the oil and fat industry in the amount of 2.5 billion rubles. On the market, depending on the degree of purification, the following range of vegetable oils are produced: unrefined, which were only subjected to mechanical cleaning; refined, neutralized; deodorized, hydrated, and others. All of them have features in the production process and each type occupies its own market segment and finds its consumers (Belyy \& Barashkov, 2020).

In the food market of vegetable oil in our country, the largest organizations are: JSC "Krasnodar MZHK”, JSC APIK "EFKO” and APG "South of Russia”, JSC "Valuysky plant of vegetable oils", Bunge Ltd (TNK). Analysts note that the share of these manufacturers is $53.8 \%$ of the vegetable oil market. And in each of these companies, there is a specialization for $80-90 \%$ of sales volume under one main brand (grade) (Alto Consulting Group, 2017).

Figure 1: Market shares of greatest producers of vegetable oil in Russia (in \%)

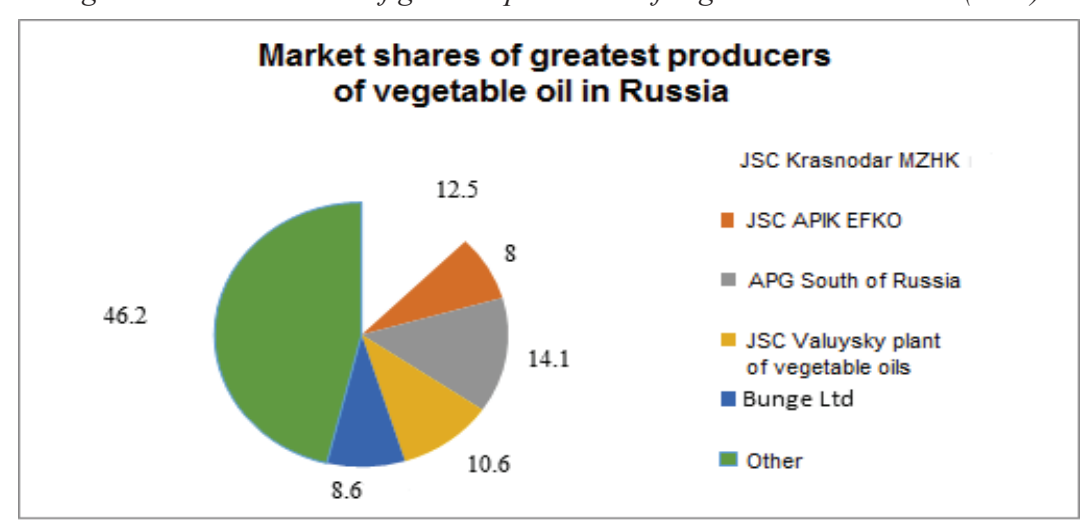

Source: Alto Consulting Group, 2017 
The chart shows that the largest share in the structure of food of the vegetable oil market of our country is agriculture "South of Russia" - 14.1\%; smallest - ZAO APIK "EFKO" - 8\% in the other group consists of a small enterprise on manufacture of vegetable oil, which is 46.2 per cent (Figure 1).

Today, there is an increase in sales of vegetable oil by wholesale organizations. These volumes include the sale of vegetable oil by regional enterprises mainly processing organizations and they form up to $90 \%$ of all purchases of products by wholesale organizations.

Questions of increase of competitiveness of the oil industry were investigated by the number scientists and institutions ( Bakievym \& Jacotot, 2017; Dontsova \& Donets, 2007; Yermolov \& Koto, 2007; Svechnikova \& Figurnov, 2007; Federal Law No. 52FZ; Federal Law No. 102 - FZ; Technical Regulation CU 022/2011; Vinogradova et al., 2014; Association of producers and consumers of fat and oil products (APMP), 2017; Russian and world vegetable oil markets, 2013).

The economic literature presents a wide variety of foreign and domestic methods and approaches to study the factors of the external and internal environment that affect the competitiveness of industrial organizations. In the practice of Russian and international analysts, the assessment and analysis of the competitiveness of the organization and its products is based on the use of the following sources of information: accounting and financial reporting data; information received from independent analytical agencies, tax authorities, as well as presented in the media about the organization and the industry as a whole.

In our opinion, traditionally the assessment of the competitiveness of organizations is carried out according to various criteria and groups of indicators:

- quality: the index of the level of prices for products; consumers ' opinion about the quality of products, compliance with the range of manufactured products to the needs of consumers, the frequency of updating the range; prestige and reputation of the organization, information support of production and sale of products; the use of competitive advantages;

- quantitative: use of the market potential of the organization; market share; state and level of use of material and technical base; availability of profit; availability of own working capital; innovative management of competitiveness factors.

The choice of criteria and indicators for assessing the competitiveness of the organization and products depends on the goal and the need to improve the organizational management of the production of goods.

It should be noted that today it is important to consider the assessment of the competitiveness of vegetable oil production as a separate independent unit, taking into account the factors and environmental conditions of organizations. The analysis of the sources of the literature allowed a defining insufficient degree of studying of theoretical approaches to the technology of its carrying out.

The relevance and practical significance of increasing the competitiveness of the fat-and-oil industry determined the purpose and objectives of the study: to consider the current state and trends of the market of sunflower seeds, corn, olive, rapeseed processing in Russia and identify the factors that determine it, as well as to develop proposals to improve their competitiveness. 


\section{Results}

The legislation is supposed to analyse the regulatory documentation that ensures the quality and safety of vegetable oils and includes Federal Laws, Technical Regulations, State Standards. The Federal Law No. 29 - FZ "On the quality and safety of food products" defines the relationship arising in the field of food quality and safety for human health.

Federal Law No. 52-FZ "On sanitary and epidemiological welfare of the population" provides sanitary and epidemiological welfare of the population as one of the key conditions for the implementation of the constitutional rights of citizens to health care and a safe environment.

Federal Law No. 102 - FZ "On ensuring the uniformity of measurements" regulates the relations arising at performance of measurements, establishment and observance of rules to measurements, measurement units, measurement standards of measurement units, standard specimens, measuring instruments, application of standard samples, measuring instruments, methods (methods) of measurements, and implementing activities on ensuring the uniformity of measurements envisaged by the legislation of the Russian Federation on ensuring the uniformity of measurements, including at performance of works and rendering of services on ensuring the uniformity of measurements.

Federal Law No. 104-FZ “On technical regulation” regulates relations arising in the development, adoption, application and execution of mandatory requirements for products, including buildings and structures, or to products and related product requirements processes of design (including research), production, construction, installation, commissioning, operation, storage, transportation, sale and disposal.

Technical regulation CU 005/2011 "On packaging safety" applies to all types of packaging, including capping agents, which are finished products released into circulation in the customs territory of the Customs Union, regardless of the country of origin.

Figure 2. Realization of the purposes of the Strategy of development of food and processing industry till 2020 in oil and fat industry

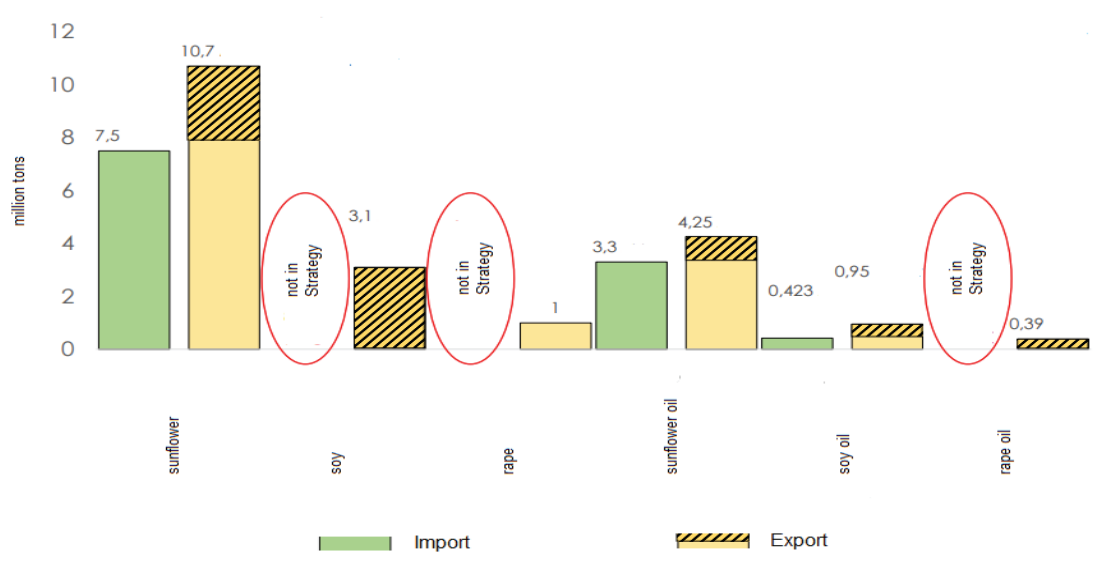

Source: Association of producers and consumers of fat and oil products (APMP), 2017 
In the world market of sunflower oils Russia, Ukraine and Argentina are recognized as the main rival states.

The Russian market of sunflower oil is aimed at 3 directions:

1. realization of vegetable oils to the population and application in public catering system;

2. application in fat-and-oil, canning and fish sectors;

3. application for the manufacture of soap and paints.

The fat-and-oil industry leads the non-primary non-energy export of medium-sized agricultural products by a huge margin. The green color in figure 2 shows the import of vegetable oils, and the yellow color shows the export of vegetable oils. Basically, as you can see in the figure, sunflower oil is imported and exported.

Commodity experts forecast an increase in competition in the oil processing industry, which is confirmed by an increase in the market share of large companies and a decrease in the share of local producers. In addition, there will be a decrease in the share of production of vegetable oils from soybeans, rapeseed. But there is also a positive dynamics of development.

Figure 3. The demand for different vegetable oils (in \%)

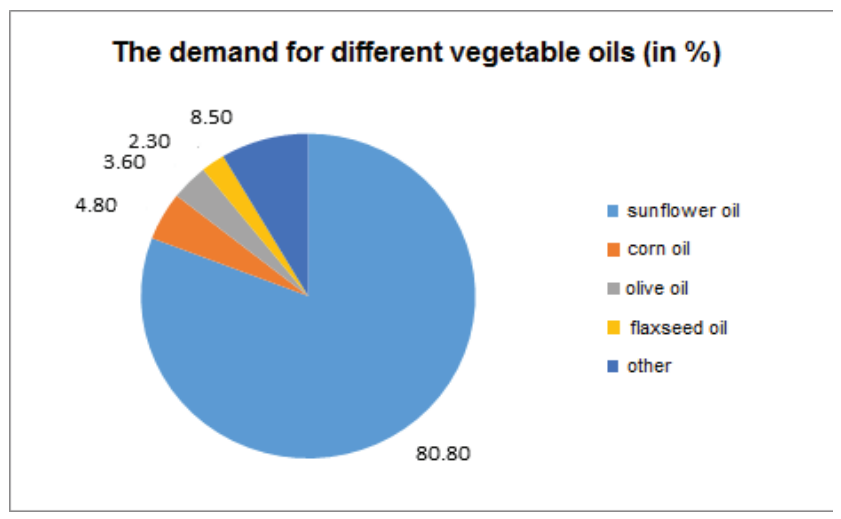

Source: Mavrina \& Mokronosov, 2007

The figure 3 shows that the greatest demand in the vegetable oil market is sunflower oil - the share of this segment is $80.8 \%$. In second place in consumption is corn oil, which occupies $4.8 \%$. The share of this type of oil also shows a positive growth rate, but the price is more expensive than sunflower. The olive oil segment by volume covers only $3.6 \%$ of the market, the Flaxseed oil segment $2.3 \%$. All olive oil presented on the Russian market is imported from abroad. Other vegetable oils (rapeseed, soybean, peanut, cotton, etc.) account for $8.5 \%$ of the market.

The figure 4 shows that the price structure of the vegetable oil market is as follows:

- $\quad$ olive oil is more expensive.

- $\quad$ on the $2^{\text {nd }}$ place is corn oil.

- $\quad$ on the $3^{\text {rd }}$ place according to the price is sunflower oil.

- $\quad$ the $4^{\text {th }}$ place in value includes the following types of oil: rapeseed, soybean, peanut, cotton, etc. 
Figure 4. Prices for different vegetable oils

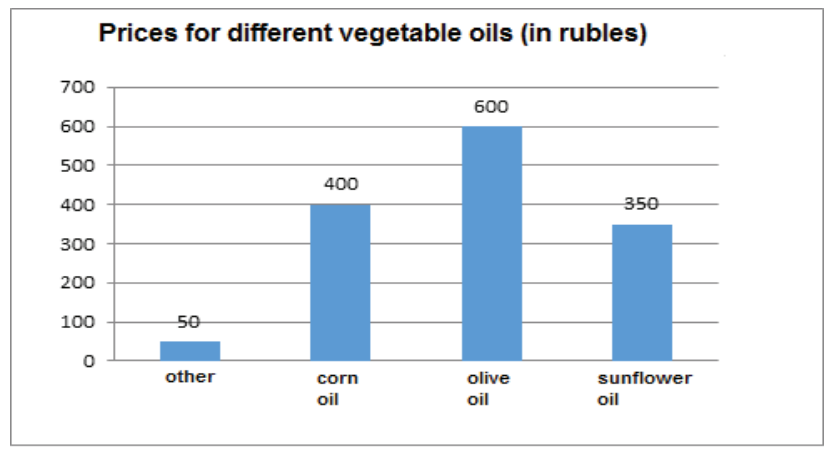

Source: Belyy \& Barashkov, 2020

The degree of consumption of vegetable oil depends on the region. The regional structure of the vegetable oil market differs significantly from the all-Russian one. The information is shown in figure 5:

- $\quad$ in the Northwest, the proportion of corn oil is well above the national average of $10.1 \%$.

- $\quad$ in the South, the share of corn oil is slightly below the level of consumption and is $7.2 \%$.

- $\quad$ in the Capital region and the Volga region, the share of corn and sunflower oil is $86.1 \%$.

- $\quad$ in the Ural region $-3.2 \%$, in the Central region - $3.1 \%$, in the far East $-2.7 \%$, in Siberia - $1.7 \%$.

After analyzing the above data, it is possible to trace the decline in the share of sunflower oil in the remote Northern and far Eastern regions. This trend is associated with the impossibility of growing oilseeds in remote regions and proximity to other countries (for example, China), which import other vegetable oils to these regions, thereby forming a demand for them.

Consumption of vegetable oils is equally distributed across all regions. This is due to the traditional diet and the habit of Russians to choose sunflower oil. But in some regions it is still significantly less than in others. For example, in the far East, the share of sunflower oil is $66.4 \%$, and the share of other types of vegetable oil (soybean, corn) there also covers $30.3 \%$. This is due to the fact that the region is remote from the key areas of sunflower cultivation, and in addition, the proximity of China, which supplies inexpensive oil raw materials for the manufacture of other types of vegetable oil (Agribusiness, 2015).

The new economic framework calls on food companies to take other strategic approaches to increase competitiveness. The competitiveness of food products depends on many factors, among which there are causal relationships. These factors are:

1. The human factor - the effectiveness of the enterprise is determined by the competencies, knowledge of employees. Of particular importance in food enterprises acquires competent qualified personnel.

2. Price factors - have a great influence on the cost of production. Price factors include: production costs; sales price; raw material costs; operating costs. 
The cost of a product expresses not only the costs of production and the relations between producers and consumers, but also the level of income of the population, marketing management systems that make it possible to effectively apply a variety of pricing strategies.

3. Non-price competitiveness factors are not only internal information, purchasing power, but also the time limits within which management decisions are made.

4. Internal factors - influence of internal economic activity. These factors determine the ability of the enterprise to ensure its competitiveness (the potential of marketing services, industrial level, financial, economic, scientific and personnel potential, the concept and means of sales promotion, the level of service and warranty service, storage, transportation, packaging of products, providing production with the necessary resources).

5. External factors - environmental impact (state-level measures aimed at influencing economic, investment, depreciation, tax policy).

6. Product quality - a direct impact on the quality characteristics of competitiveness.

Figure 5. Regional structure of the vegetable oil consumption

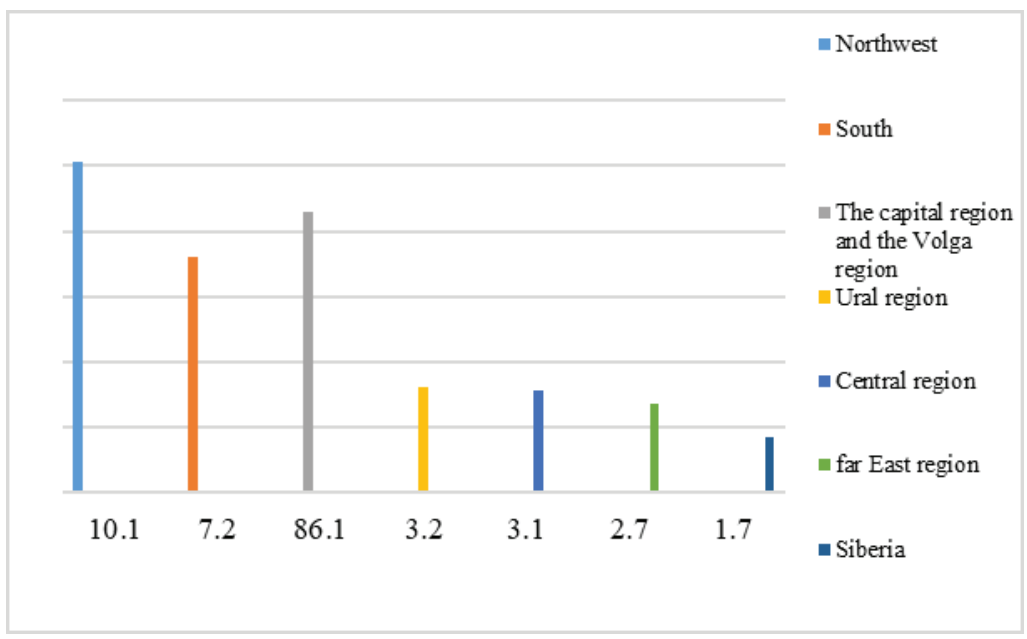

Source: Association of producers and consumers of fat and oil products (APMP), 2017

The structure of estimated characteristics of competitiveness of production contains 2 groups of parameters: qualitative and economic.

Qualitative indicators reflect the totality of the properties and characteristics of the product that give it the ability to meet the conditioned or anticipated needs. Quality contains many components. These include characteristics of destination of the product, feasibility, environmental indicators etc. To assess the level of competitiveness of production is impractical and very difficult application of all quality indicators.

One of the sources of information for the definition and evaluation of quality indicators is marketing research conducted on the basis of surveys and questionnaires 
of consumers. The competitiveness of products is assessed using criteria that make it possible to identify the most important characteristics of the goods for consumers, which are the main factors of its competitiveness. By improving the characteristics of goods, an enterprise can best increase the competitiveness of its own products.

The most common way to assess the competitiveness of products is the index method. It is based on the analysis of comparison of qualitative and cost indicators of the product under study with the requirements of the market, i.e. buyers. In practice, due to the complexity of obtaining complete and accurate information about the needs of the buyer, the competitiveness of products is evaluated indirectly with the help of a sample product. In this case, the basis is taken, not a need, but a sample product or a basic product that is in maximum demand in the market and, therefore, acting in the form of materialized average requirements for competitive products.

The index method involves assessing the competitiveness of products using single and group parametric indicators, as well as generalizing (integral) indicator (Krainova \& Palitzina, 2016).

Single indicators determine the degree of satisfaction of the buyer's needs and are calculated as the ratio of the value of the particular quality parameter or economic parameter of the analyzed goods to the value of the same parameter at which the element of the need is fully satisfied. Formulas for calculating the unit parametric index of qualitative parameters have the form:

$$
\begin{aligned}
& q i=P i / P i 6 \\
& q i=P i \sigma / P i
\end{aligned}
$$

where:

qi is the unit parametric index of the i-th qualitative parameter of the goods;

$\mathrm{Pi}$ is the value of the $\mathrm{i}$-th qualitative parameter of the analyzed product;

Pi6 is the value of the i-th qualitative parameter of the base product.

Formula (1) is used for qualitative indicators on which the competitiveness of products is directly proportional (for example, productivity - the higher the productivity of the equipment, the higher its competitiveness). Formula (2) is applied when the quality parameter affects the competitiveness of the product (for example, fuel consumption the higher the fuel consumption, the lower the competitiveness of the machine). In this way, you can make calculations on all quality parameters, resulting in a complete set of indicators characterizing the deviation of the properties of the analyzed product from the requirements of the buyer, expressed in the base product.

There is a close relationship between the production of oilseeds and the processing industry. The increase in the production of vegetable oils, as well as the expansion of their range largely depends on the development of the material and raw material base and the structure of the production of oilseeds (Gusev, 2011; Mavrina \& Mokronosov, 2007).

The main types of agricultural raw materials in Russia for the production of vegetable oils are sunflower seeds, soybeans and rapeseed (Table 1); seeds of other oil plants (flax, mustard, castor, hemp, etc.) are processed in relatively small volumes. 
Table 1. Technical and economic indicators of the fat-and-oil industry in Russia in 2018

\begin{tabular}{|l|l|}
\hline Total production of vegetable oils & $3034.8 \mathrm{kt}$ \\
\hline Average annual capacity of oilseeds processing & $9194.1 \mathrm{kt}$ \\
\hline Index of production & $98.2 \%$ \\
\hline $\begin{array}{l}\text { The share of vegetable and animal oils and fats in the total volume of } \\
\text { food products sold }\end{array}$ & $5.3 \%$ \\
\hline $\begin{array}{l}\text { The share of fixed assets of production of vegetable and animal oils } \\
\text { and fats in the total volume of the food industry }\end{array}$ & $5.5 \%$ \\
\hline Number of employees in the industry & 39.1 thousand people \\
\hline Average monthly wages in the industry & 19.4 thousand rubles \\
\hline Average per capita consumption of vegetable oils & $16 \mathrm{~kg} /$ person / year \\
\hline
\end{tabular}

Source: Gusev, 2011

Table 2. Acreage, gross yield and yield of the main types of oilseeds in the Russian Federation in 2016-2018

\begin{tabular}{|c|c|c|c|c|c|c|}
\hline \multirow{2}{*}{ № } & \multirow{2}{*}{ Indicators } & \multirow{2}{*}{ Unit } & \multicolumn{3}{|c|}{ Years } & \multirow{2}{*}{$\begin{array}{l}2017 \text { to } \\
2016, \%\end{array}$} \\
\hline & & & 2016 & 2017 & 2018 & \\
\hline \multirow{4}{*}{1.} & Sown area & \multirow{4}{*}{000 ha } & 8020.4 & 9616 & 10447 & 108.6 \\
\hline & sunflower & & 6195.6 & 7154 & 7614 & 106.4 \\
\hline & soy & & 874.6 & 1206 & 1229 & 101.9 \\
\hline & rape & & 688.1 & 856 & 893 & 104.3 \\
\hline \multirow{4}{*}{2.} & Gross harvest of seeds & \multirow{4}{*}{$000 \mathrm{t}$} & 8185.9 & 7457 & 13115 & 175.9 \\
\hline & sunflower & & 6454.3 & 5345 & 9697 & 181.4 \\
\hline & soy & & 943.7 & 1222 & 1756 & 143.7 \\
\hline & rape & & 666.8 & 670 & 1056 & 157.6 \\
\hline \multirow{4}{*}{3.} & Yield & \multirow{4}{*}{$\begin{array}{l}\text { Centner/ } \\
\text { hectare }\end{array}$} & 11.5 & 9.9 & 13.3 & 134.3 \\
\hline & sunflower & & 11.5 & 9.6 & 13.4 & 139.6 \\
\hline & soy & & 11.9 & 11.8 & 14.8 & 125.4 \\
\hline & rape & & 12.0 & 11.0 & 12.6 & 114.5 \\
\hline & other & & 6.5 & 6.1 & 7.1 & 93.8 \\
\hline
\end{tabular}

Source: Mishulina \& Gorelova, http://articlekz.com/article/8490 
Using the table, we analyze the acreage of various oilseeds.

Figure 6. The use of acreage of the main oilseeds 2016-2018 (in \%)

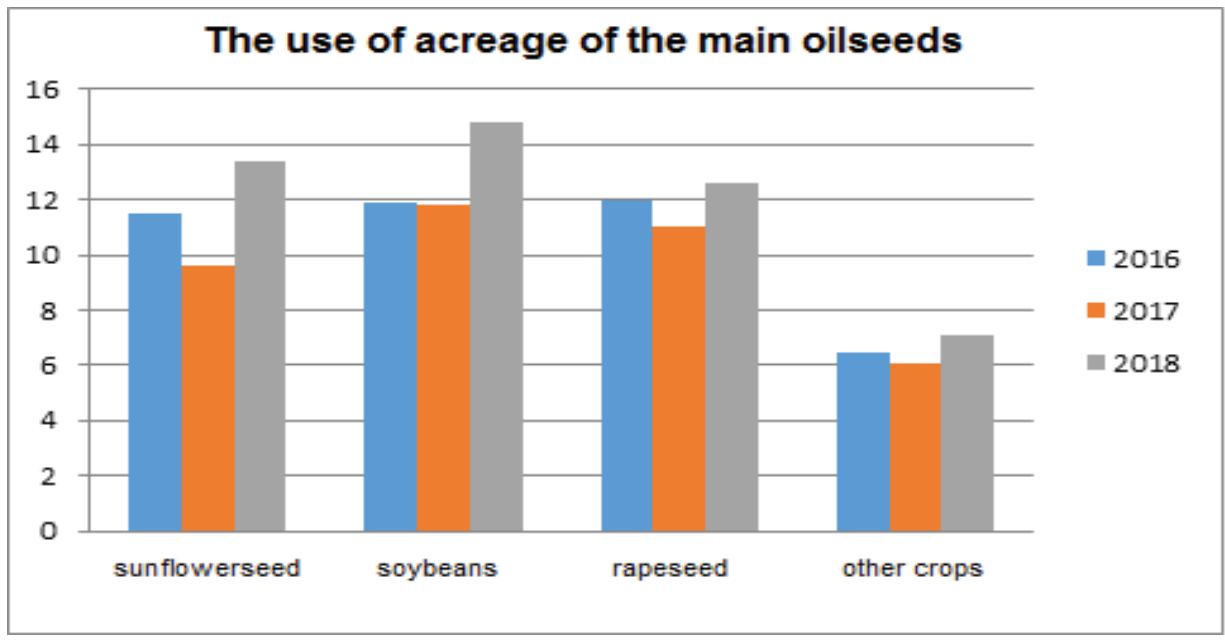

Source: Mavrina \& Mokronosov, 2007

The diagram shows that the sown areas of sunflower occupy a large area for sowing, the smallest area is occupied by other crops. Acreage of major oilseeds (sunflowerseed, soybeans and rapeseed) in the Russian Federation from 2016 to 2018, according to Rosstat, increased by $20 \%$ with 8020.4 to 9615.6 thousand hectares, including sunflower $15.5 \%$, soybean $37.8 \%$, rape by $24.4 \%$ and amounted to respectively 7153.5 thousand hectares thousand hectares 1205.7 and 855.9 thousand hectares.

Figure 7. Yield of oilseeds (in \%)

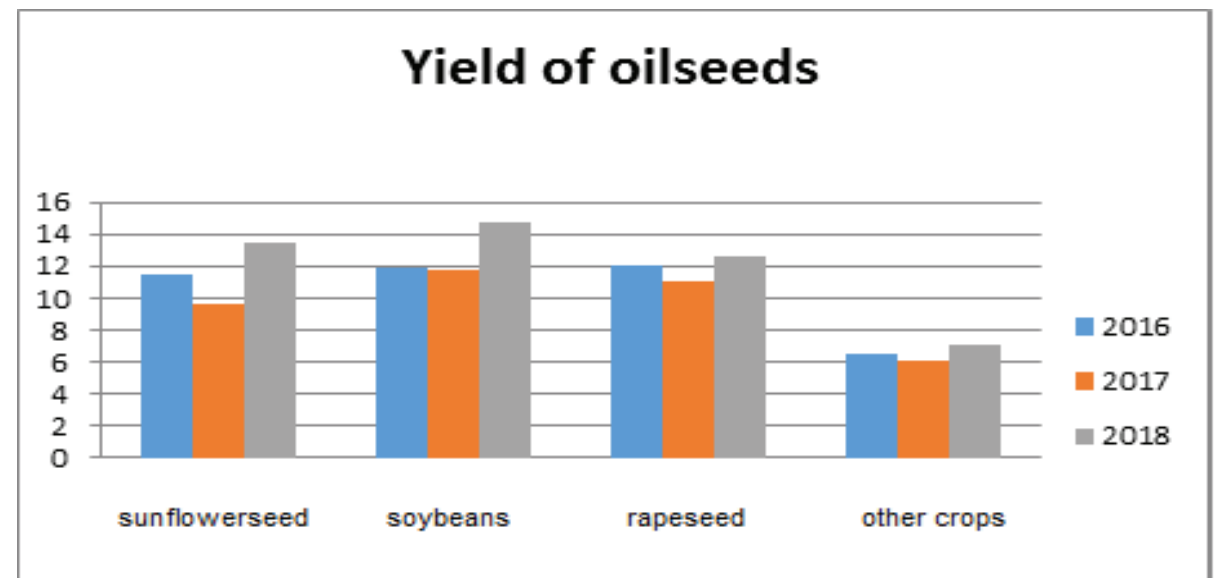

Source: Alto Consulting Group, 2017 
In 2018, the acreage for the main crops continued to increase: sunflower, rapeseed, soybeans. Increased and their productivity, which provided a significant increase in the volume of procurement of oilseeds. It should be noted the interest of agricultural producers to soybeans and rapeseed, which are made of a variety of fat and oil products. Secondary resources obtained during their processing are in great demand in the production of animal feed. In recent years, a number of regions of Central and Southern Russia have begun to show interest in flax, from which a wide range of products and flax fibers can also be obtained. This makes this culture popular for farms in terms of high income. The chart shows that in 2017 there was a decrease in the yield of the main seeds. The decrease in the yield of sunflower seeds, soybeans and rapeseed, due to the drought, did not contribute to the increase in the gross harvest of oilseeds in the country.

Next, we analyze the gross collection of seeds. The Figure 8 shows that in 2017 there was a decrease in the yield of the main seeds. The decrease in the yield of sunflower seeds, soybeans and rapeseed, due to the drought, did not contribute to the increase in the gross harvest of oilseeds in the country.

Figure 8. Gross seed harvest (in \%)

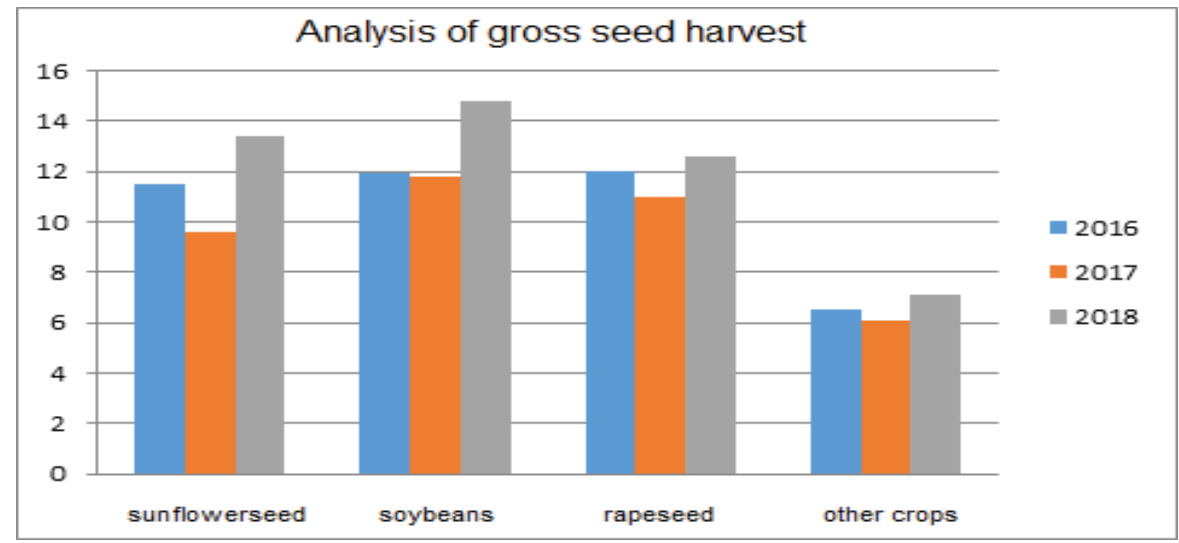

Source: Buklagin, 2019

The diagram shows that the gross harvest of oilseeds in 2017 decreased by 729.2 thousand tons and amounted to $7456.7 \mathrm{kt}$, or $91.1 \%$ to the level of 2016 . The gross yield of seeds occurred on the sunflower 1116.1 THD. MT to $5338.2 \mathrm{kt}$, or $82.7 \%$ to 2016 .

The main regions involved in the cultivation of sunflower are the Southern Federal district, Central and Volga. 
Figure 9. Major sunflower growing regions (in \%)

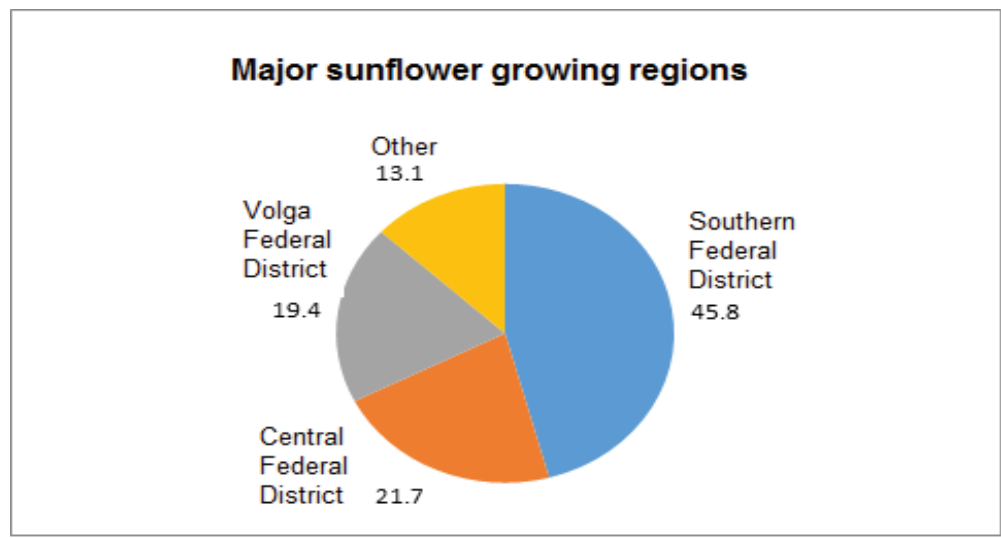

Source: Belyy \& Barashkov, 2020

The diagram shows that the main sunflower growing region is the Southern Federal District. It accounts for 45.8 per cent of production, or 2444.3 thousand tons. Central and Volga Federal districts is respectively $21.7 \%$ and $19.4 \%$ of the total production of sunflower. The rest of the regions accounts for $13.1 \%$.

The production of certain types of oilseeds depends on the natural conditions of each region of Russia, so the distribution of their cultivation in different Federal districts is different (Table 3).

The increase in the acreage occupied by rapeseed allowed to rapeseed harvest in the amount of 671.5 thousand tons, which is comparable to the volume of rapeseed production in 2017. The North Caucasus Federal district is the leader in the cultivation of rapeseed-195.6 thousand tons, or $29.1 \%$, including in the Stavropol territory - 182.3 thousand tons, or $27.1 \%$ of the domestic collection of rapeseed. The southern and Central Federal districts accounted for 21.2 and $18.7 \%$, or 142.7 and 125.8 thousand tons of rapeseed.

Last year 2018 was favorable for growing sunflower beans. The increase in acreage allowed increasing the gross harvest of sunflower beans by $29.5 \%$ to 1.2 million tons, which is 278.7 thousand tons higher than in 2017 and is a record for the last 20 years. Traditionally, the main volumes of sunflower beans are grown in the far Eastern Federal district -814.1 thousand tons, or $66.8 \%$ and in the Krasnodar region -212.9 thousand tons, or $17.5 \%$.

A characteristic feature of the last decade in the market of vegetable oils was the factor of increasing import and export of tropical vegetable oils, which have become widely used in the food industry - dairy, confectionery, bakery, oil and fat, soap and perfume and cosmetic industries. And if the use of tropical oils in the soap-making and perfumery and cosmetic industries is quite normal and meets the requirements of the technologies used, their use in industries producing socially important food products is highly questionable given their volume (Skornichenko \& Oruch, 2012). 
Table 3. Sunflower, soybean and rapeseed production volumes by Federal districts of Russia in 2017-2018, $k t$

\begin{tabular}{|c|c|c|c|c|c|c|c|c|}
\hline \multirow{2}{*}{$\begin{array}{l}\text { Federal } \\
\text { district }\end{array}$} & \multicolumn{4}{|c|}{ Sunflower } & \multicolumn{4}{|c|}{ Rape } \\
\hline & 2017 & 2018 & $2018 / 2017$ & $\begin{array}{c}\text { Share, } \\
\%\end{array}$ & 2017 & 2018 & $2018 / 2017$ & $\begin{array}{c}\text { Share, } \\
\%\end{array}$ \\
\hline $\begin{array}{l}\text { Russian } \\
\text { Federation }\end{array}$ & 6454.3 & 5338.2 & 82.7 & 100 & 666.8 & 671.5 & 100.7 & 100 \\
\hline CFD & 1555.6 & 1156.2 & 74.3 & 21.7 & 169.1 & 125.8 & 74.4 & 18.7 \\
\hline SZFO & \multicolumn{4}{|c|}{ No data } & 105.1 & 64.4 & 61.3 & 9.6 \\
\hline SFD & 2818.5 & 2444.3 & 86.7 & 45.8 & 74.9 & 142.7 & 190.4 & 21.2 \\
\hline SKFO & 349.3 & 407.6 & 116.7 & 7.6 & 105.9 & 195.6 & 184.7 & 29.1 \\
\hline PFD & 1438.8 & 1036.8 & 72.1 & 19.4 & 133.0 & 21.9 & 16.5 & 3.3 \\
\hline UFO & 7.4 & 12.6 & 169.1 & 0.2 & 13.6 & 23.9 & 175.6 & 3.6 \\
\hline SFO & 284.6 & 280.6 & 98.6 & 5.3 & 65.0 & 97.2 & 149.6 & 14.5 \\
\hline DFO & 0.1 & 0.1 & 104.5 & 0.002 & \multicolumn{4}{|c|}{ No data } \\
\hline
\end{tabular}

Source: Pilipenko et al., https://m.cyberleninka.ru/article/v/aktualnye-voprosy-upravleniyakachestvom-rastitelnogo-masla /In Russian/

The authors identified the factors affecting the competitiveness of fat and oil products and the organization. The system of factors is shown in Figure 10.

The competitiveness of products (services) depends on a number of factors that affect the preference of goods and determine the volume of their sale in a given market. These factors can be considered components (components) of competitiveness and divided into three groups: organizational and managerial, technical and economic, commercial. We have refined and supplemented the factors for the processing industry.

In addition to these factors of competitiveness of the organization allocate regulatory factors that reflect the requirements of technical, environmental and other (moral and ethical) safety of the use of goods in the market of vegetable oils, as well as patent requirements (patent purity and patent protection). In case of non-compliance of the goods with the norms and requirements of standards and legislation applicable in the period under review, the goods may not be sold. Therefore, the assessment of this group of factors and components using the compliance factor has no further continuation. This condition acts as a restriction requiring mandatory implementation of rules, norms, standards (Alto Consulting Group, 2017).

In modern conditions, there is a need to change the orientation and evaluation criteria of the developed and manufactured products. Competitiveness is determined by a set of properties of products included in the structure of its quality and significant for the consumer, determining the costs of the consumer for the acquisition, consumption and disposal of products.

As a rule, most of the enterprises of the fat-and-oil industry in the activity attract investments (in terms of providing financing), the following factors are provided: 
- the state of production facilities and the availability of an absolute cycle of processing of sunflower seeds (with an analysis of the" production " of the product at each production stage);

- $\quad$ organization of lean production in the organization;

- $\quad$ organization of business processes;

- availability of own warehouse space for storage of raw materials of plant origin, requiring maintenance of storage temperature, humidity;

- availability of raw materials (relationships with suppliers and logistics of the company's customers);

- $\quad$ availability of own distribution;

- variety of production line;

- $\quad$ climatic conditions of the region and their forecast values (for 2018-2019);

- volumes of oilseeds;

- dynamics of prices in the foreign and domestic market;

- entry of the enterprise into the group of companies (focus of the group, analysis of market share).

Having considered all the factors that have a great impact on the competitiveness of the organization and products, we can say that in modern conditions, the indicators characterizing the specifics of the fat-and-oil industry are of great importance. The authors highlight the factors: lean manufacturing in the organization and the organization of the factory processes.

Lean production is a production system based on the constant desire to eliminate all types of losses in the enterprises of the fat-and-oil subcomplex. Lean production at enterprises can not be carried out without involvement in the management, technological process of optimization and automation of production. Any lean production involves focusing on consumers and maximizing the profits of the firm (Alto Consulting Group, 2017).

The system "Lean production" makes it possible to adjust production to the needs of customers by minimizing costs. Lean manufacturing often requires large capital investments for the purchase of equipment, materials, technologies etc. to maximize the profit of the firm by changing the organizational culture of production management, system of relationships between different levels and departments of an enterprise, the system of value orientations of employees and their relationships.

Since September 2014, "Process factories" have been formed and created at the enterprises of the fat-and-oil industry that produce vegetable oils. This is the socalled "educational game", which is based on the latest technological processes for the manufacture of vegetable oils. Broadcasting the experience of a group of workers simulates the work of a small enterprise for the production of vegetable oils. Each participant has his own position-worker, controller, logistician, technologist-and his own area of responsibility. The task of the "process factory": to organize a profitable production of vegetable oils in 30 minutes and to instill skills of lean production. 
Figure 10. System of factors influencing competitiveness

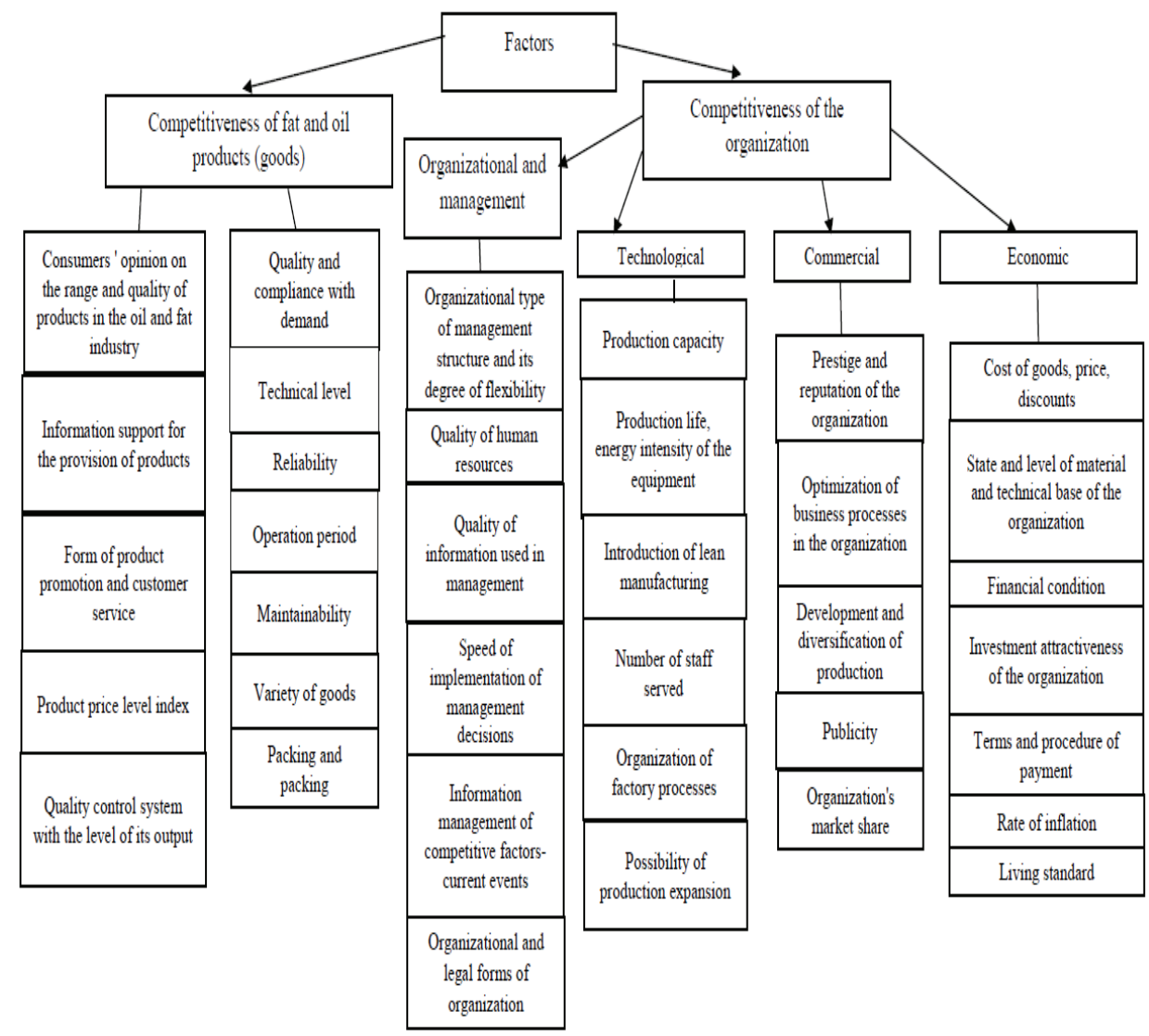

Source: Compiled by the authors

Vegetable oil companies are guided by the concept of lean production. Waste in the form of meal goes to feed production. "Process factory" is an advanced model for the development of new thinking in production and office workers. In the so-called process factories there is a development of new contracts and transformation into information, digital technologies of business. The new project "process factory" is planned to be launched at the end of 2019 at many oil processing enterprises (Dolmatova et al., 2015).

In the next 10 years there will be a significant transformation of the fat and oil industry. Of course, there will be oil processing enterprises in pure form, but combined production will increasingly take the lead. There will be other strong points of growth these are innovative developments. It is safe to say that when Russia learns to effectively manage its resources in the fat and oil industry, it will inevitably have the opportunity to actively influence the future of the world.

Thus, the competitiveness of products and organizations is dependent on the considered organizational and managerial, regulatory, innovative factors and conditions that affect the level of increasing the competitiveness of products. It is difficult to define 
and quantify this dependency, but it is an incentive to find ways to assess and improve competitiveness. Expert methods are most suitable for this purpose. It is advisable to study the impact of these factors on the preference of goods.

\section{Conclusion}

The problems of increasing the competitiveness of vegetable oil products organizations are considered one of the most important and relevant. It is necessary that they find their solution at the level of the Russian regions, because it is here that the planned projects for the processing of agricultural raw materials - oilseeds-are directly implemented. In a short period of time, efforts should be made both by the Executive power and business, so that agriculture can modernize outdated agricultural machines, use the achievements of scientific and technological progress and borrow the experience of other States on technologies of cultivation and processing of oilseeds. According to the authors, it is necessary to improve the market infrastructure in the commodity and consumer markets, to eliminate the negative impact on competition from monopolists and various intermediaries (buyers). It is necessary to facilitate the access of producers of fat and oil products to the consumer market (Pilipenko et al.).

The quality of products is the most important factor of the company in a market economy, ensuring its competitive ability and increase profits. Activities to improve product quality are carried out rationally within the framework of system management, which covers the entire life cycle of products from design to consumption and disposal.

Increasing the competitiveness of domestic fat and oil products not only gives it an advantage in the domestic food market, but also seriously affects the interests of well-known multinational companies. It is no coincidence that the export of vegetable oils has increased significantly. It is very important, increasing production volumes for the domestic market, to constantly expand the Russian presence in the international market. Thus, we can talk about a positive trend in the development of the fat-and-oil complex in Russia. The main guideline of the economic strategy of enterprises, a factor of competitiveness is considered to improve the quality and safety of products.

According to the authors, an important component of improving the competitiveness of the fat-and-oil industry is the improvement of organizational and economic tools for its implementation to determine the future strategic programs that will establish the competitiveness of the processing industry at the regional level.

\section{References}

Agribusiness. (2015) Prospects for the development of the fat-and-oil industry // online magazine about Business, Management and Economics "scarab plus". Retrieved from http://scarplus.ru/agro/perspektivyi-razvitiya-maslozhirovoy-o//In Russian/

Almazov, S. O., \& Katischin, D. S. (2014). The competitiveness of the organization from the point of view of marketing. NovaInfo.Ru. Economic science, 28, 83-88. /In Russian./ Retrieved from http://novainfo.ru/article/2680/pdf 
Alto Consulting Group. (2017). Vegetable oil market. Current situation and forecast 2017. Retrieved from http://alto-group.ru/otchot/marketing/262-rynokrastitelnogo-masla-tekushhaya-situaciya-i-prognoz-2014-2018-gg.html /In Russian/

Association of producers and consumers of fat and oil products (APMP). (2017). Global trends in the market of vegetable oils in 2016-2017. Retrieved from http://nkoapmp.org/мировые-тенденции-на-рынке-раститель//In Russian/

Bakievym, G. L. \& Jacotot, D. H. (2017). Innovative component of increasing the competitiveness of consumer cooperation organizations. Bulletin of the Belgorod University of cooperation, Economics and Law, 1, 336-339.

Belyy E. M., \& Barashkov. S. V. (2020). Semantic analysis of the concept of competitiveness. Retrieved from http://diplomba.ru/work/35128 /In Russian/

Buklagin, D. S. (2019). Analysis of the use of oilseeds of domestic and foreign selection. International research journal, 9(2), 34 -41. Retrieved from https:// research-journal.org/agriculture/analiz-ispolzovaniya-semyan-maslichnyxkultur-otechestvennoj-i-inostrannoj-selekcii/. doi: 10.23670/IRJ.2019.87.9.032

Dashkov, L. P. (2007). Commerce and technology of trade. LLC "ITC "Dashkov and K".

Dolmatova, I. A., Miller, D. E., Lapteva, M. D., Bystrova, A. A. (2015). Relevance of the organization of "lean production" in public catering. Young scientist, 23, 137-140. Retrieved from https://moluch.ru/archive/103/23968/

Dontsova, V., \& Donets, Y. Y. (2007). Competitiveness of the enterprise. Chapter 3: Overview of competitiveness. Retrieved from http://uchebnik.biz/book/686konkurentosposobnost-predpriyatiya/6-3-obzor-opredelenij-ponyatiyaquotkonkurentosposobnost-predpriyatiyaquot.html /In Russian/

Federal Law No. 102 - FZ “On ensuring the uniformity of measurements”. Retrieved from http://www.consultant.ru/cons/cgi/online.cgi?req=doc;base=LAW;n=182748\#0

Federal Law No. 104 - FZ “On technical regulation”. Retrieved from http://www. consultant.ru/cons/cgi/online.cgi?req=doc;base $=\mathrm{LAW}$; $=196382 \# 0$

Federal Law No. 29 - FZ “On the quality and safety of food products”. Retrieved from http://www.consultant.ru/cons/cgi/online.cgi?req=doc;base=LAW;n=182922

Federal Law No. 52-FZ “On sanitary and epidemiological welfare of the population”. Retrieved from http://www.consultant.ru/cons/cgi/online.cgi?req=doc;base=LA $\mathrm{W} ; \mathrm{n}=201176 \# 0$

Gusev, V. R. (2011). External and internal factors of turnover and ways to increase sales of retail trade organizations. Lab books.

Krainova, O. S., \& Palitzina, D. V. (2016). To the question about the quality control of consumer goods the Focus to the merchandise. Journal of the Institute of management and socio-economic development, 12 (31), 1577-1583. Retrieved from http://iupr.ru/domains_data/files/zurnal_31/KraynovaO.S..pdf/In Russian/

Kutaeva, T. N., \& Palitsyna, D. V. (2017). Essential characteristics of competitiveness of the organizations of the processing industry. Accounting and analytical tools for the development of innovative economy: Russian and European experience. 
Volume I. IX all-Russian scientific and practical conference. Knyaginino, November 23-24, 2017. ). Retrieved from https://docviewer.yandex.ru/ view/81595393/

Mavrina I. N., \& Mokronosov, A. G. (2007). Competitiveness of the enterprise. Chapter 3: Overview of competitiveness. Retrieved from http://uchebnik. biz/book/686-konkurentosposobnost-predpriyatiya/6-3-obzor-opredelenijponyatiya-quotkonkurentosposobnost-predpriyatiyaquot.html

Mishulina, O. V., \& Gorelova, N. S.. The main directions of increasing the efficiency of production at the enterprise. Scientific articles of Kazakhstan. Economy. Retrieved from http://articlekz.com/article/8490

Pilipenko T. V., Nilova, L. P., Naumenko, N. V., \& Mekhtiev, V. S.. Topical issues of quality management of vegetable oils, pp. 185-187. Retrieved from https://m. cyberleninka.ru/article/v/aktualnye-voprosy-upravleniya-kachestvomrastitelnogo-masla/In Russian/

Retrieved from http://uchebnik.biz/book/686-konkurentosposobnost-predpriyatiya/63-obzor-opredelenij-ponyatiya-quotkonkurentosposobnost-predpriyatiyaquot. html /In Russian/

Russian and world vegetable oil markets. (2013). News of food processing industry in Russia and CIS. Food industrial portal. Marketing. Market review. Retrieved from https://carbofood.ru/obzory-rynkov/mirovoi-rynok-rastitelnogo-maslatendencii-i-prognozy /In Russian/

Skornichenko N. N. (2012). Improvement of the mechanism of increase of competitiveness of enterprises in the service sector to improve service quality. Economy and management: new challenges and prospects, 3, 288-291 /In Russian/

Svechnikova, S. G. \& Figurnov, E. B. (2007). Product quality management: Studies.

Technical Regulation CU 022/2011 "Food products in terms of its labeling". Retrieved from http://www.consultant.ru/cons/cgi/online.cgi?req=doc;base=LA $\mathrm{W} ; \mathrm{n}=124614 \# 0$

Technical Regulation CU 024/2011 “On fat and oil products”. Retrieved from http:// www.consultant.ru/cons/cgi/online.cgi?req=doc;base=LAW;n=197849\#0

Technical Regulation TS 021/2011 “On food safety”. Retrieved from http://www. consultant.ru/cons/cgi/online.cgi?req=doc;base=LAW;n=164427\#0

The CU technical Regulation 005/2011 “On safety of packaging”. Retrieved from http://www.consultant.ru/cons/cgi/online.cgi?req=doc;base=LAW;n=164466\#0

Vinogradova, N. I. (2014). Innovative component of the growth of competitiveness of consumer cooperation organizations. Bulletin of the Belgorod University of cooperation, Economics and Law, 1, 336-339.

Yermolov, M. O., \& Koto, T. (2007). Main directions of increasing the efficiency of production at the enterprise. Scientific articles of Kazakhstan. Economy. Retrieved from http://uchebnik.biz/book/686-konkurentosposobnost-predpriyatiya/6-3obzor-opredelenij-ponyatiya-quotkonkurentosposobnost-predpriyatiyaquot.html /n Russia 